\title{
Mg and La Co-doped ZnO Nanoparticles Prepared by Sol- gel Method: Synthesis, Characterization and Photocatalytic Activity
}

\author{
Behnam Khanizadeh', Morteza Khosravi ${ }^{1}$, Mohammad A. Behnajady ${ }^{2 *}$, Ali Shamel ${ }^{3}$, Behrouz Vahid ${ }^{4}$ \\ 1 Department of Applied Chemistry, North Tehran Branch, Islamic Azad University, Tehran 1651153311, Iran \\ 2 Department of Chemistry, Tabriz Branch, Islamic Azad University, Tabriz 5157944533, Iran \\ ${ }^{3}$ Department of Chemistry, Ardabil Branch, Islamic Azad University, Ardabil 5615731567, Iran \\ ${ }^{4}$ Department of Chemical Engineering, Tabriz Branch, Islamic Azad University, Tabriz 5157944533, Iran \\ * Corresponding author, e-mail: behnajady@iaut.ac.ir
}

Received: 07 August 2018, Accepted: 02 October 2018, Published online: 23 April 2019

\begin{abstract}
In this study, La and Mg doped, and co-doped ZnO nanoparticles were prepared using the sol-gel method. The prepared samples were characterized by X-ray diffraction (XRD), field emission scanning electron microscopy (FESEM), energy dispersive X-ray spectroscopy (EDX), transmission electron microscopy (TEM), UV-Vis diffuse reflectance spectroscopy (DRS), and $\mathrm{N}_{2}$ physisorption techniques. The XRD results indicated that the prepared nanoparticles can be well adopted by the hexagonal wurtzite structure crystal and there are no second impurity peaks. Studies of the FESEM, EDX and TEM have shown that the samples have uniform spherical-like morphology with a homogenous distribution. The incorporation of $\mathrm{La}$ and $\mathrm{Mg}$ into the $\mathrm{ZnO}$ lattice had no effect on the morphology of the nanoparticles, but a reduction in the size of the grains $\left(\approx 14 \mathrm{~nm}\right.$ to $\approx 7 \mathrm{~nm}$ ) was observed due to the insertion of these ions. The results of $\mathrm{N}_{2}$ physisorption indicated that there was an increase in BET surface area and pore volume for doped and co-doped samples. The results of DRS showed an increase in band gap energy and a blue shift at the absorption edge for doped and co-doped samples. The photocatalytic activity of the prepared catalysts was evaluated in the removal of RhB under UVA irradiation. The results showed that Mg5\%-La5\%/ZnO had the highest photoactivity (91.18\%) among all samples.
\end{abstract}

Keywords

heterogeneous photocatalysis, co-doped ZnO, photocatalytic activity, Rhodamine B, sol-gel method

\section{Introduction}

The vast consumption of water in various industries, particularly in color production, leads to remarkable wastewater which can pollute the environment. Hence, for preventing water pollution, it is necessary to remove organic compounds before they are discharged into wastewater [1-8]. Since 1 to $20 \%$ of the overall produced dyes are released into the environment $[2,8,9]$, this procedure is considered as a notable concern and an international problem for human beings [10]. Due to the production of toxic metabolites [2], especially aromatic amines [9], these pollutants are regarded as poisonous $[5,9,11,12]$, resistant to biological treatment [2, $5,11]$, stable in environment [2] and carcinogenic [12, 13]. The presence of organic materials in wastewater consumes dissolved oxygen $[2,7]$, reduces the process of photosynthesis, and decreases the solubility of gases [7, 12]. Adsorption, ultrafiltration, reverse osmosis, coagulation, sedimentation, and ozone treatment are assumed as traditional treatment methods which have disadvantages such as high costs, production of toxic sludge, ineffective degradation and low mineralization of organic dyes, nondestructive decolorization, producing secondary pollution and high treatment time $[2,5,7,12-16]$. New development in water treatment has led to the technology of Advanced Oxidation Processes (AOPs) which are widely used for mineralizing toxic pollutants and a variety of recalcitrant organics in wastewaters $[2,3,7,8$, 16-20]. Given different AOPs, heterogeneous photocatalysis is regarded as an effective and promising technique $[4,12,13]$.

In the heterogeneous photocatalysis, a semiconductor photocatalyst is excited by UV irradiation which forms electron-hole pairs. Hydroxyl radicals and reactive oxygen species (ROS) with high oxidation potential are produced 
subsequent reactions. These species are mainly responsible for oxidizing organic pollutants, especially aromatic rings.

Notable instances of photocatalysts are $\mathrm{ZnO}, \mathrm{TiO}_{2}$, $\mathrm{Zn}_{2} \mathrm{SnO}_{4}, \mathrm{WO}_{3}, \mathrm{~V}_{2} \mathrm{O}_{5}, \mathrm{CdS}, \mathrm{Cu}_{2} \mathrm{O}, \mathrm{W}_{2} \mathrm{O}_{5}, \mathrm{Fe}_{2} \mathrm{O}_{3}, \mathrm{ZnS}, \mathrm{ZrO}_{2}$, $\mathrm{CeO}_{2}$ and etc. [1, 13, 19, 21, 22]. Significant merits of $\mathrm{ZnO}$ are as follows: i) heterogeneous photocatalyst [9, 23-35], ii) more efficiency than $\mathrm{TiO}_{2}$ under UV light [1, 7, 20, 22, 35, 36], iii) high transformation of organic component [37], iv) high activity in removing organic contaminants [23], v) high luminescent activity [35], vi) high activity surface due to large number of active sites [1] and vii) absorption of an extensive range of UV spectrum [22]. However, $\mathrm{ZnO}$ has low quantum efficiency due to high recombination electron-hole pairs $[5,7]$. With respect to UV irradiation on $\mathrm{ZnO}$ surface, charge separation should be very fast after the generation of electron-hole pairs for delaying the recombination process [9]. The recombination rate of the electron-hole pairs can be reduced by coupling with other metal oxides [38-41] and also by doping and co-doping of metal and nonmetal ions into the photocatalyst lattice [4, $19,22,26,29,30,34-36,42-53]$. The sol-gel method is a very versatile process for homogeneous doping or co-doping of ions into the $\mathrm{ZnO}$ lattice $[54,55]$.

Behnajady et al. [56], noted a superior photocatalytic activity for $\mathrm{Mg}$-doped $\mathrm{TiO}_{2}$ in comparison with un-doped $\mathrm{TiO}_{2}$ for the degradation of C.I. Acid Red 27. The highest photocatalytic activity of $\mathrm{Mg}$-doped $\mathrm{TiO}_{2}$ in comparison with other $\mathrm{M}$-doped $\mathrm{TiO}_{2}$ catalysts $(\mathrm{M}=\mathrm{Fe}, \mathrm{Co}, \mathrm{Ce}$, $\mathrm{Cr}, \mathrm{Mn}, \mathrm{Ni}$ and $\mathrm{Ag}$ ions), was defined by Feng et al. for the degradation of Rhodamine B in an aqueous solution [57]. Wang et al. [58], informed an improved photocatalytic activity for $\mathrm{Ag} / \mathrm{ZnO}-\mathrm{SnO}_{2}$ photocatalyst in compared with pure $\mathrm{ZnO}-\mathrm{SnO}_{2}$ in degradation $\mathrm{MO}$. In recent years, some studies have been done on preparing co-doped $\mathrm{ZnO}$ such as, Al-Sn/ZnO, Li-Mg/ZnO, Gd-ZnO:Al, Al-Na/ZnO, $\mathrm{Mn}-\mathrm{Co} / \mathrm{ZnO}, \mathrm{N}-\mathrm{Li} / \mathrm{ZnO}, \mathrm{Li}-\mathrm{Mg} / \mathrm{ZnO}, \mathrm{Eu}-\mathrm{Er} / \mathrm{ZnO}, \mathrm{Ni}-\mathrm{Cu} /$ $\mathrm{ZnO}, \quad \mathrm{Al}-\mathrm{Li} / \mathrm{ZnO}, \mathrm{Al}-\mathrm{N} / \mathrm{ZnO}, \mathrm{Cu}-\mathrm{V} / \mathrm{ZnO}, \mathrm{Ag}-\mathrm{S} / \mathrm{ZnO}$, Ga-N/ZnO, Al-N/ZnO, Mg-Ga/ZnO, Y-Cd/ZnO, Cd-Al/ $\mathrm{ZnO}, \mathrm{N}-\mathrm{In} / \mathrm{ZnO}$ and $\mathrm{Al}-\mathrm{Ga} / \mathrm{ZnO}$ [59-61].

In line with the purpose of the present study for enhancing $\mathrm{ZnO}$ photocatalytic activity $[4,14,19,22], \mathrm{ZnO}, \mathrm{Mg}$ / $\mathrm{ZnO}, \mathrm{La} / \mathrm{ZnO}$ and $\mathrm{Mg}-\mathrm{La} / \mathrm{ZnO}$ nanoparticles were synthesized by sol-gel method. To the best of our knowledge, there is no report concerning the co-doping of $\mathrm{ZnO}$ with $\mathrm{Mg}$ and La. The structural properties of the prepared catalyst were characterized by using X-ray diffraction (XRD), scanning electron microscopy (SEM), transmission electron microscopy (TEM), UV-Vis diffuse reflectance spectroscopy (DRS) and specific surface area and porosity analysis (BET \& BJH). The catalytic activity of nanoparticles was investigated with regard to removing Rhodamine $\mathrm{B}(\mathrm{RhB})$ under ultraviolet light (UVA).

\section{Experimental}

\subsection{Materials}

Zinc acetate di-hydrate $\left(\mathrm{Zn}\left(\mathrm{CH}_{3} \mathrm{COO}\right)_{2} \cdot 2 \mathrm{H}_{2} \mathrm{O}\right.$, Merck), Lanthanum nitrate hexa-hydrate $\left(\mathrm{La}\left(\mathrm{NO}_{3}\right)_{3} \cdot 6 \mathrm{H}_{2} \mathrm{O}\right.$, Merck), Magnesium nitrate hexa-hydrate $\left(\mathrm{Mg}\left(\mathrm{NO}_{3}\right)_{2} \cdot 6 \mathrm{H}_{2} \mathrm{O}\right.$, Merck) were used as sources of $\mathrm{Zn}, \mathrm{La}$ and $\mathrm{Mg}$, respectively. Oxalic acid di-hydrate and ethanol (99.99\%) were also purchased from Merck and used without further purification. Rhodamine B (Merck) was used as model contaminant for the photocatalytic activity experiments. Double distilled water was used in all experiments.

\subsection{Synthesis of nanoparticles using sol-gel method}

Bimetallic Mg-La/ZnO, monometallic $\mathrm{Mg} / \mathrm{ZnO}$ and $\mathrm{La} /$ $\mathrm{ZnO}$ and pure $\mathrm{ZnO}$ were prepared by using sol-gel method. For the co-doped $\mathrm{ZnO}$ nanoparticles with 5-6 wt.\% $\mathrm{Mg}$ and 4-5 wt. \% La, at first zinc acetate di-hydrate was slowly dissolved in $100 \mathrm{~mL}$ ethanol at $60^{\circ} \mathrm{C}$ (with thermal controlling) and ongoing stirring for $30 \mathrm{~min}$ until homogeneous solution was obtained. Then, appropriate amounts of $\mathrm{Mg}\left(\mathrm{NO}_{3}\right)_{2}$ and $\mathrm{La}\left(\mathrm{NO}_{3}\right)_{3}$ dissolved in $20 \mathrm{~mL}$ ethanol at $60{ }^{\circ} \mathrm{C}$ were used which were continuously stirred for 30 min until homogeneous solution was obtained and was added drop by drop to the ethanolic solution of zinc acetate (where temperature was controlled). The oxalic acid, dissolved in ethanol $(40 \mathrm{~mL})$ at $60^{\circ} \mathrm{C}$, was added drop by drop to the ethanolic solution. The mixture was stirred for $2 \mathrm{~h}$. The obtained white colloidal semi-gel dried at $90{ }^{\circ} \mathrm{C}$ for $12 \mathrm{~h}$ in the oven (E24-Sherwood Co). The dried xerogel was calcinated at $400{ }^{\circ} \mathrm{C}$ for $2 \mathrm{~h}$ in the electric Furnace (ALF-18-iran, Atbin Co). It was powdered by mortar. Doped $\mathrm{Mg} / \mathrm{ZnO}$ and $\mathrm{La} / \mathrm{ZnO}$ nanoparticles with 1-6 wt. \% and bare $\mathrm{ZnO}$ were also prepared by the similar procedure $[4,26,35,62,63]$.

\subsection{Photocatalytic experiments}

All experiments regarding photocatalytic degradation were carried out in a batch $100 \mathrm{~mL}$ volume quartz photoreactor with a $35 \times 2.5 \mathrm{~cm}$ dimension which was fixed parallel to UVA light source. During the reaction, oxygen gas was entered from the bottom of the photoreactor. UV-A (Hitachi, F15T8/BL, $15 \mathrm{~W}, \lambda_{\text {max }}=370 \mathrm{~nm}$ ) was the irradiation source. During the photocatalytic reaction, 
evaporation could be neglected because the solution temperature did not increase significantly. For photocatalytic $\mathrm{RhB}$ degradation through $\mathrm{ZnO}$ nanoparticle (bare, doped and co-doped), $50 \mathrm{~mL}$ of aqueous $\mathrm{RhB}$ solution with fixed weight of catalyst $(20 \mathrm{mg})$ was sonicated for $15 \mathrm{~min}$ in ultrasonic bath (Sonica-2200ETH, Italy, 260W, $40 \mathrm{kHz}$ in dimension of $24 \times 14 \times 10 \mathrm{~cm}$ ). The aqueous $\mathrm{RhB}$ solution (10 $\mathrm{mg} \mathrm{L}^{-1}$ ) including the photocatalyst was transferred to the batch quartz photoreactor and bubbled with an oxygen flow to keep the suspension homogeneous (flow rate $=0.5 \mathrm{~mL} \mathrm{~min}^{-1}$ ) for $15 \mathrm{~min}$ in the darkness. The reaction was initiated by turning on the UVA lamp and $5 \mathrm{~mL}$ suspension solution was taken at a certain irradiation time (21 min); then, the nanoparticles were separated by centrifuge (Kokusan H-11n). RhB Concentration was analyzed by UV-Vis spectrophotometer (Biowave-S2100, WPA) at $\lambda_{\max }=554 \mathrm{~nm} .[4,19,26]$.

\subsection{Characterization methods}

The crystalline phase and average crystallite size of the synthesized $\mathrm{ZnO}$ (bare, doped and co-doped) nanoparticles were characterized using XRD technique via analytical-X'pert Pro-X-ray diffractometer. XRD patterns were recorded using $\mathrm{Cu} \mathrm{k} \alpha$ irradiation $(\lambda=0.154 \mathrm{~nm})$ operator at $40 \mathrm{kV}$ and $100 \mathrm{~mA}$ in the diffraction range $(2 \theta)$ between 10 to $80^{\circ}$. The average crystallite size, i.e. D (nm), of the obtained nanoparticles was calculated by Scherrer's equation [64]. The morphology and size of particles were determined by FESEM technique (MIRA3-TE-SCAN Co). FESEM was equipped with an energy dispersive X-ray spectroscopy (EDX) system for analyzing the chemical composition of nanoparticles. The morphology and average size of the nanoparticles were analyzed by TEM (EM10C-100kV-Zeiss, Germany). The optical band gap energy of nanoparticles was obtained by UV-Vis diffuse reflectance spectroscopy (DRS, UV-2550, Shimadzu, Japan). The results of the DRS were converted to the Tauc equation. The optical band gap of nanoparticles can be calculated by Tauc equation (Eq. (1)).

$\alpha h v=A(h v-E g)^{n}$

where $E g$ refers to the optical band gap; $h$ denotes Planck's constant; $v$ refers to the frequency of incident photons; $A$ stands for a constant which is called the band tailing parameter; $\alpha$ refers to the absorption coefficient $(\alpha=4 \pi k / \lambda) ; k$ is the absorption index or absorbance; $\lambda$ denotes the wavelength in $\mathrm{nm}$ ) and $n$ refers to the index which depends on the type of transition and may have values such as $3 / 2$,
1/2, 2 and 3 corresponding to direct forbidden, direct allowed, indirect allowed and indirect forbidden transitions, respectively.

The band gaps of insulators/semiconductors are categorized into allowed direct and indirect band gaps. Hence, the value of $n$ should be 0.5 in equation [1] for allowed direct band gap. The average band gap can be derived by plotting Tauc's graphs between $(\alpha h v)^{2}$ versus photon energy $(h v)$ and by extrapolating the linear portion of the spectra to the hv axis [65-70]. The wavelength of absorption edge $(\lambda)$ was obtained from equation $E g=1239.8 / \lambda$. $[22,47,63] . \mathrm{N}_{2}$ adsorption and desorption experiments were carried out at $77 \mathrm{~K}$ using the BET analyzer (Belsorp Mini) so as to measure specific surface area and pore size distribution based on BET (Brunauer-Emmett-Teller) and BJH (Barret-Joyner-Halender) methods.

\section{Results and discussion 3.1 XRD structural studies}

The XRD patterns of the nanoparticles $\mathrm{ZnO}, \mathrm{Mg} 5 \% / \mathrm{ZnO}$, $\mathrm{La} 4 \% / \mathrm{ZnO}, \mathrm{Mg} 5 \%$-La5\%/ZnO and $\mathrm{Mg} 6 \%$-La4\%/ZnO are depicted in Fig. 1. All peaks can be well adopted by the hexagonal wurtzite structure crystal according to the standard XRD pattern of ZnO (JCPDS 36-1451) [71]. It appears from the XRD analysis that there are no second impurity peaks corresponding to $\mathrm{MgO}$ and $\mathrm{La}_{2} \mathrm{O}_{3}$. The absence of characteristic reflections related to the $\mathrm{Mg}$ and $\mathrm{La}$ in the XRD pattern of $\mathrm{Mg}$ and/or $\mathrm{La} / \mathrm{ZnO}$ (doped and co-doped) samples may be attributed to the low loading quantity and appropriate incorporation of $\mathrm{La}$ and $\mathrm{Mg}$ ions in the $\mathrm{ZnO}$ lattice [22]. The $2 \theta$ value for (101) diffraction peak $(\mathrm{ZnO}$ main peak) in the XRD patterns of $\mathrm{ZnO}, \mathrm{Mg} 5 \% / \mathrm{ZnO}$, $\mathrm{La} 4 \% / \mathrm{ZnO}, \mathrm{Mg} 5 \%-\mathrm{La} 5 \% / \mathrm{ZnO}$ and $\mathrm{Mg} 6 \%-\mathrm{La} 4 \% / \mathrm{ZnO}$ are $36.343^{\circ}, 36.265^{\circ}, 36.343^{\circ}, 36.369^{\circ}$ and $36.447^{\circ}$, respectively. The ionic radius of $\mathrm{Mg}$ ions $(0.72 \AA)$ is close to the $\mathrm{Zn}$ ions $(0.74 \AA)$ but the radius of the La ions $(1.03 \AA)$ is larger than that of $\mathrm{Zn}$ ions. The shift in the $2 \theta$ values and the broadening of the diffraction peaks indicate that the doped ions are successfully incorporated into the $\mathrm{ZnO}$ lattice. Due to the notable difference between $\mathrm{La}$ and $\mathrm{Zn}$ ionic radiuses, it is difficult for La to substitute $\mathrm{Zn}$ and La ions are incorporated only in the interstitial sites of the $\mathrm{ZnO}$ lattice [72]. Nevertheless, $\mathrm{Mg}$ might be able to substitute $\mathrm{Zn}$ because of the same ionic radius. The average crystallite size of the nanoparticles was measured from X-ray line broadening of the (101) diffraction peak by means of Debye-Scherrer's equation. The results, given in Table 1, obviously indicate the reduction of $\mathrm{ZnO}$ crystalline size by doping $\mathrm{La}$ and 


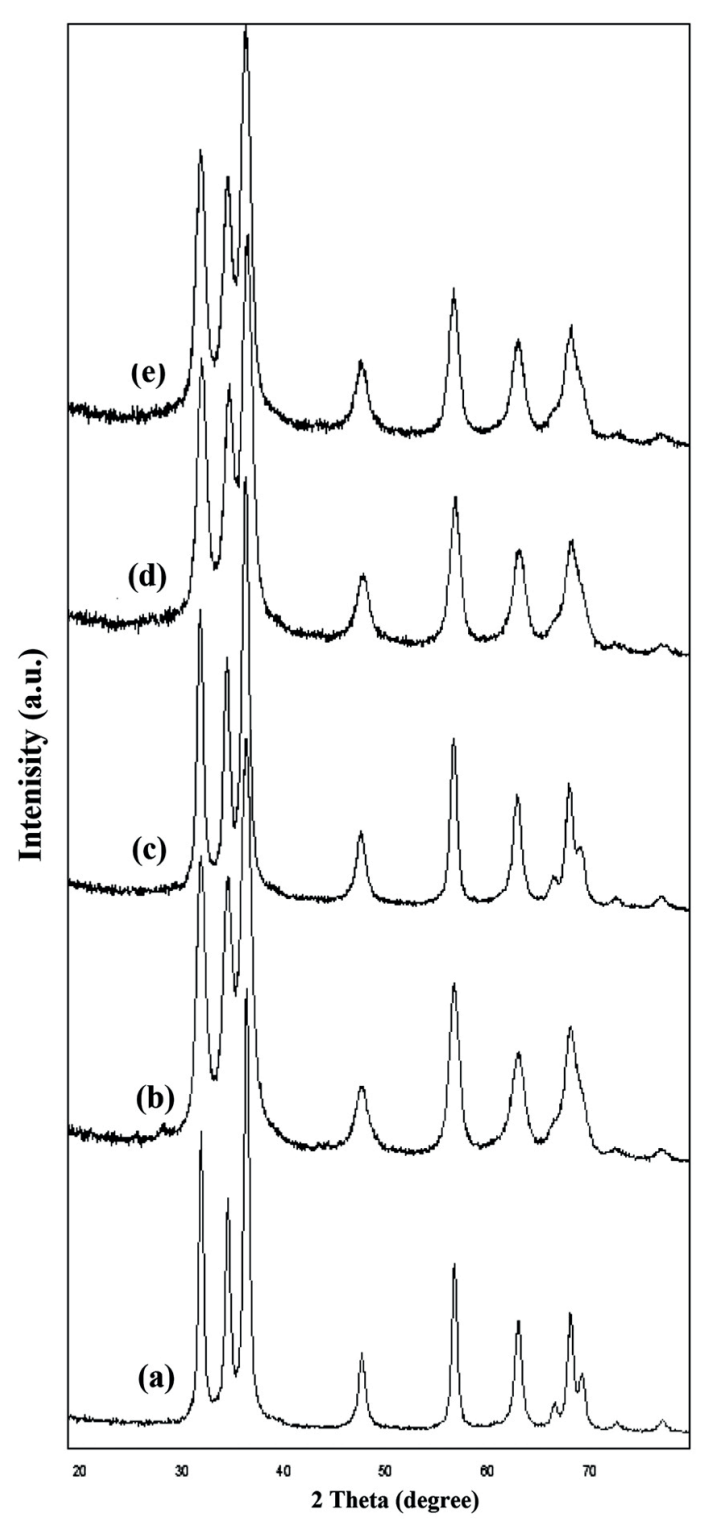

Fig. 1 XRD patterns of (a) $\mathrm{ZnO}$, (b) $\mathrm{Mg} 5 \% / \mathrm{ZnO}$, (c) $\mathrm{La} 4 \% / \mathrm{ZnO}$, (d) $\mathrm{Mg} 5 \%-\mathrm{La} 5 \% / \mathrm{ZnO}$, and (e) $\mathrm{Mg} 6 \%-\mathrm{La} 4 \% / \mathrm{ZnO}$ nanoparticles.

$\mathrm{Mg}$. The reduction in crystallite size is mainly attributed to the presence $\mathrm{La}-\mathrm{O}-\mathrm{ZnO}$ and $\mathrm{Mg}-\mathrm{O}-\mathrm{ZnO}$ on the surface of the doped $\mathrm{ZnO}$, which excludes the growth of crystalline grains [26]. In addition, the doping and co-doping of $\mathrm{Mg}^{2+}$ and $\mathrm{La}^{3+}$ ions lead to oxygen vacancies in the $\mathrm{ZnO}$ crystalline structure; consequently, its crystallite size decreases. Due to different $\mathrm{La}$ and $\mathrm{Mg}$ positions in the $\mathrm{ZnO}$ lattice, the impact of $\mathrm{Mg}$ doping on the crystallite size was more significant and effective than that of La doping. The microstrain $(\varepsilon)$ can be calculated using in Eq. (2) [29].

$\varepsilon=\beta \cos \theta / 4$

As shown in Table 1, there is a slight change in microstrain values. That is, the increased micro-strain in nanoparticles changes the diffraction peak broadening which results in a reduction of particle size and a little shift in the XRD peaks. However, it should be pointed out that the line broadening may be due to the size or microstrain or the interaction between both of them [29]. The cell parameters of prepared samples in Table 1 indicates that the lattice parameter (a) of co-doped nanoparticles are slightly higher than other samples.

\subsection{FESEM and EDS studies}

FESEM is considered to be a useful technique in studying the structural characterization and morphology of nanoparticles. It has information about the growth mechanism, shape and size of the particles [29]. Fig. 2 (a)-(e) illustrates FESEM images and the surface morphology of bare, doped and co-doped $\mathrm{Mg}, \mathrm{La} / \mathrm{ZnO}$ nanoparticles. It shows that the samples have a uniform spherical-like morphology with a homogenous distribution. Indeed, FESEM images obviously demonstrate that the doping and co-doping of $\mathrm{Mg}^{2+}$ and $\mathrm{La}^{3+}$ have no impact on the morphology of $\mathrm{ZnO}$ nanoparticles; nevertheless, it shows that the size of the grains has decreased, especially in the co-doped sample. In addition to FESEM, EDS analysis was conducted for investigating the chemical composition of nanoparticles. The results of the EDS analysis are depicted in the Fig. 3(a)-(e) and Table 2. EDS spectra of bare $\mathrm{ZnO}$ have only two elements, namely $\mathrm{Zn}$ and $\mathrm{O}$ which indicates that $\mathrm{ZnO}$ sample is pure. In addition, doped and co-doped nanoparticles were formed only from $\mathrm{Zn}, \mathrm{Mg}, \mathrm{La}$ and $\mathrm{O}$ elements and the purity of the

Table 1 Crystallits size, cell parameters and micro-strain of $\mathrm{ZnO}, \mathrm{Mg}$, La doped and co-doped nanoparticles.

\begin{tabular}{lcccccc}
\hline Nanoparticle & $2 \theta$ & FWHM $(\beta)$ & Crystallite & Micro-strain & \multicolumn{2}{c}{ Cell parameters } \\
\cline { 5 - 7 } & $(\mathrm{deg})$ & $(\mathrm{rad})$ & size $(\mathrm{nm})$ & $10^{-3}$ & $\mathrm{a}=\mathrm{b}(\AA)$ & $\mathrm{c}(\AA)$ \\
\hline $\mathrm{ZnO}$ & 36.343 & 0.0101 & 14.28 & 2.4 & 3.2200 & 5.2000 \\
$\mathrm{Mg} 5 \% / \mathrm{ZnO}$ & 36.265 & 0.0199 & 7.25 & 4.7 & 3.2190 & 5.1490 \\
$\mathrm{La} 4 \% / \mathrm{ZnO}$ & 36.343 & 0.0134 & 10.79 & 3.2 & 3.2190 & 5.1490 \\
$\mathrm{Mg} 5 \%-\mathrm{La} 5 \% / \mathrm{ZnO}$ & 36.369 & 0.0194 & 7.45 & 4.6 & 3.2490 & 5.2050 \\
$\mathrm{Mg} 6 \%-\mathrm{La} 4 \% / \mathrm{ZnO}$ & 36.447 & 0.0197 & 7.33 & 4.7 & 3.2500 & 5.2070 \\
\hline
\end{tabular}




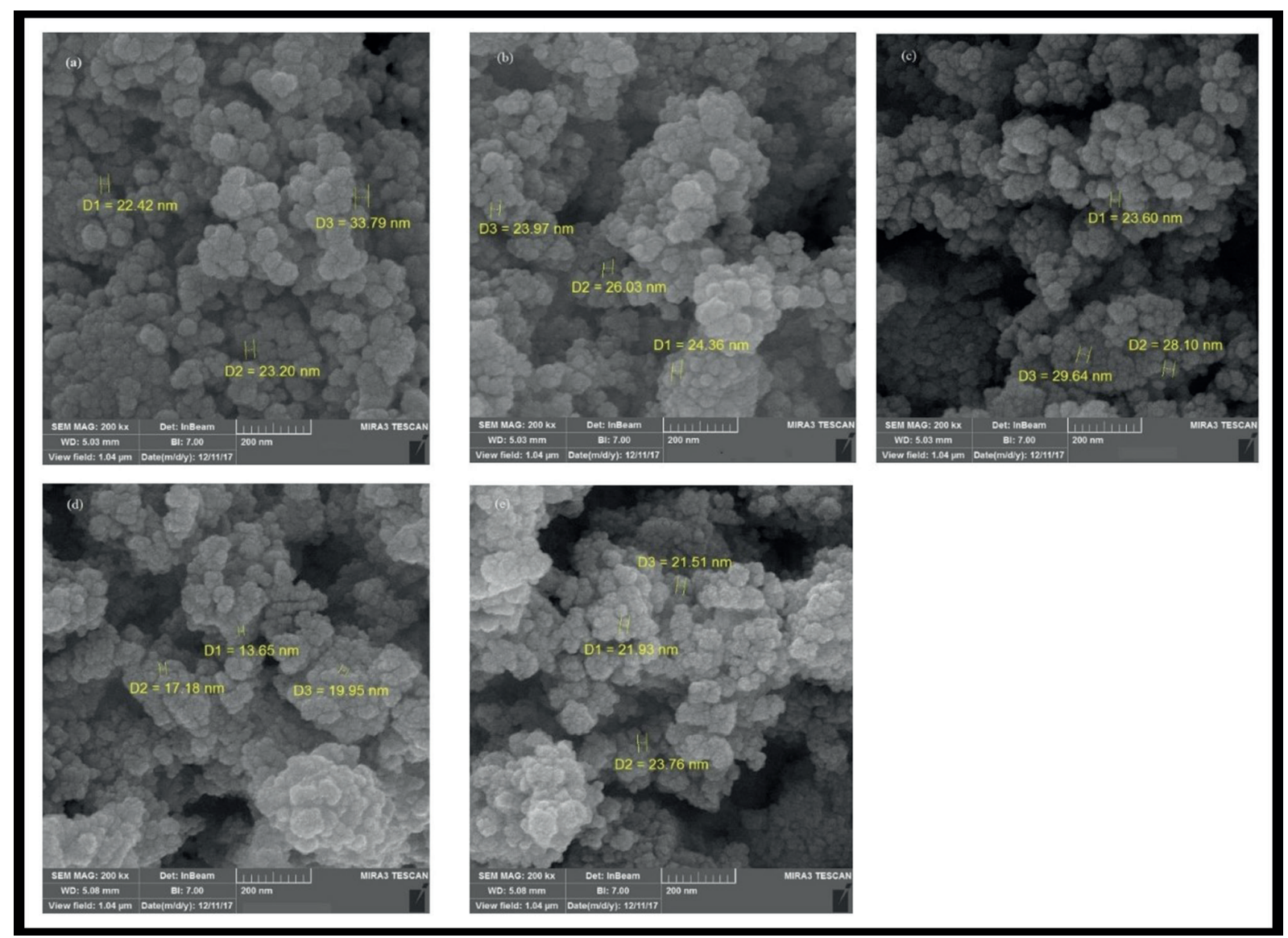

Fig. 2 (a)-(e): FESEM images for (a) $\mathrm{ZnO}$, (b) $\mathrm{Mg} 5 \% / \mathrm{ZnO}$, (c) $\mathrm{La} 4 \% / \mathrm{ZnO}$, (d) $\mathrm{Mg} 5 \%-\mathrm{La} 5 \% / \mathrm{ZnO}$ and (e) $\mathrm{Mg} 6 \%-\mathrm{La} 4 \% / \mathrm{ZnO}$

nanoparticles was confirmed. The quantitative analysis of the compositional elements such as $\mathrm{Zn}, \mathrm{O}, \mathrm{Mg}$ and $\mathrm{La}$ in the prepared nanoparticles is shown in Table 2. The EDX analysis confirms the presence of $\mathrm{Mg}$ and $\mathrm{La}$ in $\mathrm{ZnO}$ and also indicates good compatibility with the experimental concentration used for the synthesis of nanoparticles.

\subsection{TEM images}

The shape and size of the particles and their distribution for the prepared nanoparticles are depicted in TEM images (Fig. 4(a)-(e)). TEM images of all samples indicate some agglomeration along with individual particles. According to these images, all prepared photocatalysts have regular distributions and spherical morphology. The size obtained from XRD differs from those of TEM techniques. Whereas the grain size, in TEM, is measured as the distance between visible grain boundaries, the extent of the crystalline region which coherently diffracts X-rays is measured as the grain size in XRD. Consequently, it can be argued that XRD leads to smaller size in comparison with other methods such as TEM and SEM [63]. The particle size distributions based on TEM images for all

Table 2 The quantitative analysis of the compositional elements present in the bare, $\mathrm{Mg}$ and $\mathrm{La}$ doped and co-doped $\mathrm{ZnO}$ nanoparticles.

\begin{tabular}{|c|c|c|c|c|c|c|c|c|c|c|c|c|}
\hline \multirow{3}{*}{ Samples } & \multicolumn{12}{|c|}{ Percentage of the element } \\
\hline & \multicolumn{4}{|c|}{ Weight $\%$} & \multirow{2}{*}{$\begin{array}{l}\mathrm{Mg} / \mathrm{Zn} \\
\text { ratio\% }\end{array}$} & \multirow{2}{*}{$\begin{array}{l}\mathrm{La} / \mathrm{Zn} \\
\text { ratio\% }\end{array}$} & \multicolumn{4}{|c|}{ Atomic $\%$} & \multirow{2}{*}{$\begin{array}{l}\mathrm{Mg} / \mathrm{Zn} \\
\text { ratio\% }\end{array}$} & \multirow{2}{*}{$\begin{array}{l}\mathrm{La} / \mathrm{Zn} \\
\mathrm{ratio} \%\end{array}$} \\
\hline & $\mathrm{Zn}$ & $\mathrm{O}$ & $\mathrm{Mg}$ & $\mathrm{La}$ & & & $\mathrm{Zn}$ & $\mathrm{O}$ & $\mathrm{Mg}$ & $\mathrm{La}$ & & \\
\hline $\mathrm{ZnO}$ & 79.80 & 20.20 & --- & --- & --- & --- & 49.15 & 50.85 & --- & --- & --- & --- \\
\hline $\mathrm{Mg} 5 \% / \mathrm{ZnO}$ & 66.09 & 30.62 & 3.29 & --- & 4.98 & --- & 34.08 & 63.93 & 1.99 & --- & 5.84 & --- \\
\hline $\mathrm{La} 4 \% / \mathrm{ZnO}$ & 62.47 & 35.09 & --- & 2.44 & --- & 3.91 & 32.36 & 66.49 & --- & 1.15 & --- & 3.55 \\
\hline $\mathrm{Mg} 5 \%-\mathrm{La} 5 \% / \mathrm{ZnO}$ & 58.32 & 35.68 & 3.01 & 2.99 & 5.16 & 5.13 & 38.65 & 57.31 & 2.22 & 1.82 & 5.74 & 4.71 \\
\hline $\mathrm{Mg} 6 \%-\mathrm{La} 4 \% / \mathrm{ZnO}$ & 56.46 & 37.67 & 3.35 & 2.52 & 5.93 & 4.46 & 36.12 & 60.05 & 2.31 & 1.52 & 6.39 & 4.21 \\
\hline
\end{tabular}




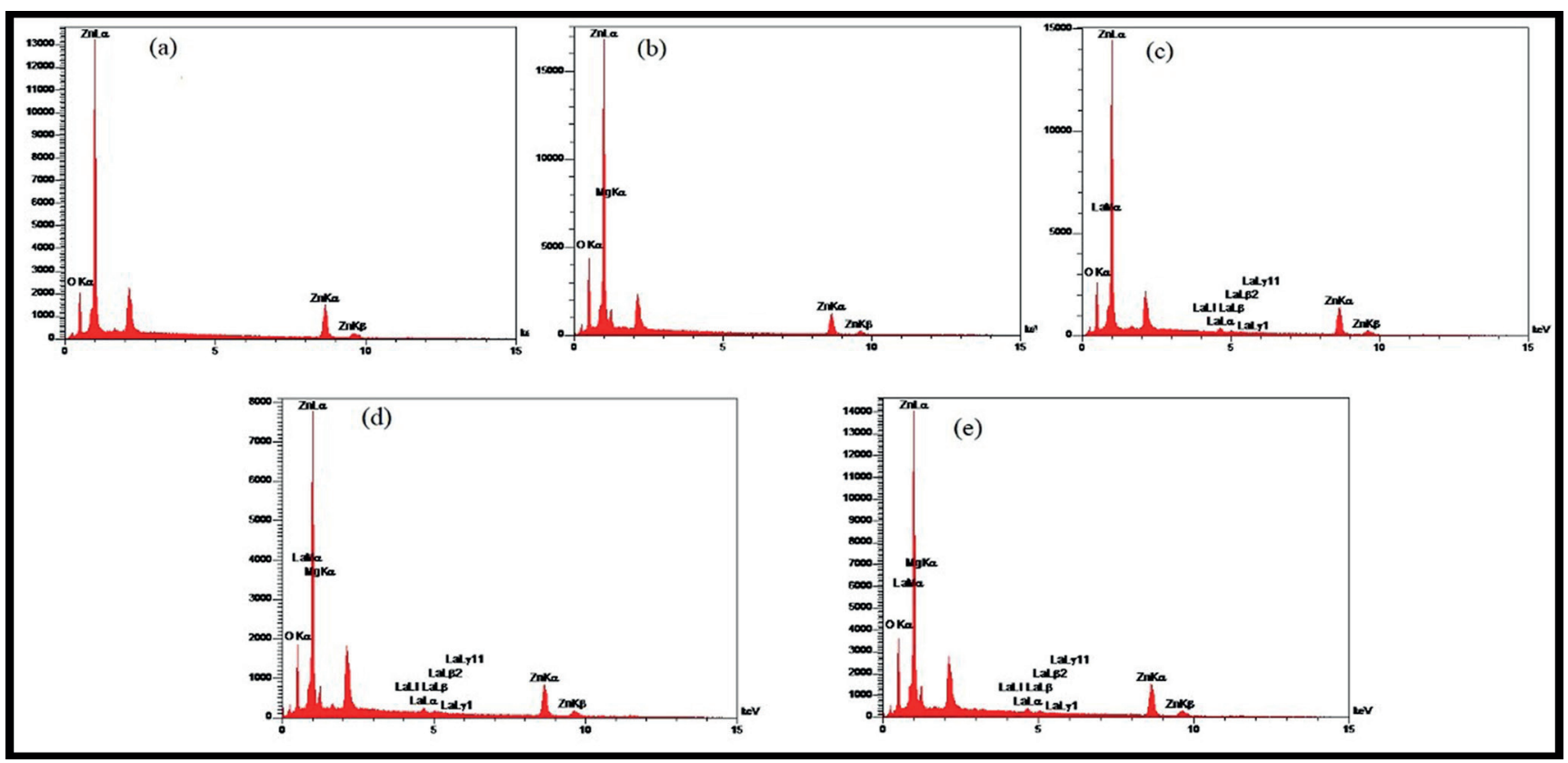

Fig.3 (a)-(e) EDS spectra of (a) bare $\mathrm{ZnO}$, (b) $\mathrm{Mg} 5 \% / \mathrm{ZnO}$, (c) $\mathrm{La} 4 \% / \mathrm{ZnO}$, (d) $\mathrm{Mg} 5 \%-\mathrm{La} 5 \% / \mathrm{ZnO}$, and (e) $\mathrm{Mg} 6 \%-\mathrm{La} 4 \% / \mathrm{ZnO}$

Table 3 Surface area and pore characterization achieved by the BET and BJH methods.

\begin{tabular}{lcccc}
\hline Photocatalyst & $\begin{array}{c}\text { BET Surface area } \\
\left(\mathrm{m}^{2} \mathrm{~g}^{-1}\right)\end{array}$ & $\begin{array}{c}\text { Total Pore Volume } \\
\left(\mathrm{cm}^{3} \mathrm{~g}^{-1}\right)\end{array}$ & $\begin{array}{c}\text { Mean Pore Diameter } \\
(\mathrm{nm})\end{array}$ & $\begin{array}{c}\mathrm{r}_{\mathrm{p}} \text {. Peak (Area) } \\
(\mathrm{nm})\end{array}$ \\
\hline $\mathrm{ZnO}$ & 45.183 & 0.2728 & 24.148 & 14.44 \\
$\mathrm{Mg} 5 \% / \mathrm{ZnO}$ & 72.087 & 0.5159 & 28.628 & 5.35 \\
$\mathrm{La} 4 \% / \mathrm{ZnO}$ & 46.104 & 0.3130 & 27.159 & 12.2 \\
$\mathrm{Mg} 5 \%-\mathrm{La} 5 \% / \mathrm{ZnO}$ & 63.621 & 0.4678 & 29.409 & 5.35 \\
$\mathrm{Mg} 6 \%-\mathrm{La} 4 \% / \mathrm{ZnO}$ & 54.774 & 0.3859 & 28.178 & 5.35 \\
\hline
\end{tabular}

samples are shown in Fig. 5. The histograms indicate that the average particle size of $\mathrm{ZnO}, \mathrm{Mg} 5 \% / \mathrm{ZnO}, \mathrm{La} 4 \% / \mathrm{ZnO}$, $\mathrm{Mg} 5 \%-\mathrm{La} 5 \% / \mathrm{ZnO}$ and $\mathrm{Mg} 6 \%-\mathrm{La} 4 \% / \mathrm{ZnO}$ is about 28.55 , $17.62,23.71,16.06$ and $13.38 \mathrm{~nm}$, respectively. These values were obtained from 569, 540, 618, 490 and 567 particles, respectively. The results reveal that the particle size of nanoparticles is reduced as a result of doping $\mathrm{Mg}$ and $\mathrm{La}$ into the $\mathrm{ZnO}$ lattice.

\subsection{BET surface area analysis}

Figs. 6(a) and 6(b) depict the $\mathrm{N}_{2}$ adsorption-desorption isotherms and the pore size distribution for the prepared samples, respectively. According to IUPAC classification, $\mathrm{N}_{2}$ adsorption-desorption isotherms of the nanoparticles show a type III isotherm which indicates the presence of the mesoporous and macroporous structure [73-76].

The results regarding BET surface area and total pore volume in Table 3 indicate increased surface area and pore volume for the doped and co-doped samples. In the sol-gel technique, crystal growth was suppressed by the addition of $\mathrm{La}$ and $\mathrm{Mg}$ dopants. Hence, as acknowledged by XRD results, crystallite size decreases; consequently, surface area increases. Moreover, higher surface area values for the doped samples may be attributed to the removal of nitrate from the $\mathrm{ZnO}$ lattice during calcination at $400{ }^{\circ} \mathrm{C}$ and the thermal decomposition of $\mathrm{La}$ and $\mathrm{Mg}$ precursors [10]. Thus, increasing the porosity of the surface enhances the surface area [10].

\subsection{DRS studies}

UV-Vis DRS of nanoparticles are depicted in Fig. 7. The absorption edge of $\mathrm{Mg} 5 \% / \mathrm{ZnO}, \mathrm{La} 4 \% / \mathrm{ZnO}$, and $\mathrm{Mg} 6 \%-\mathrm{La} 4 \% / \mathrm{ZnO}$ are slightly blue shift when compared with bare $\mathrm{ZnO}$ nanoparticles. Tauc equation $[65,66]$ was applied for calculating Eg and absorption edge (Fig. 8). The band gap and absorption edge values for nanoparticles are given in Table 4 . $\mathrm{ZnO}$ band gap value was enhanced by the doping and co-doping of $\mathrm{La}$ and $\mathrm{Mg}$ elements. The results reveal that doping with $\mathrm{Mg}$ lead to $0.072 \mathrm{eV}$ enhancement in the band gap energy. The resulting $0.039 \mathrm{eV}$ difference 


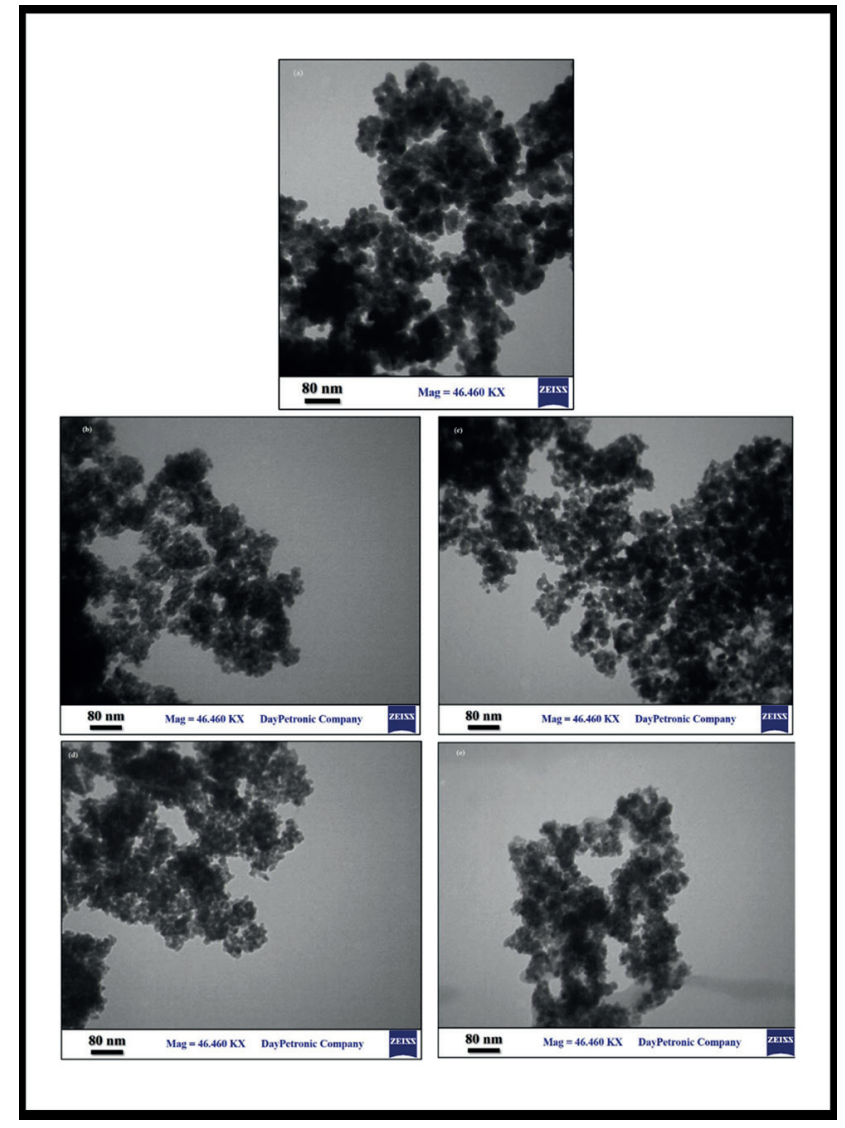

Fig. 4 (a)-(e) TEM images for (a) $\mathrm{ZnO}$, (b) $\mathrm{Mg} 5 \% / \mathrm{ZnO}$, (c) $\mathrm{La} 4 \% / \mathrm{ZnO}$, (d) $\mathrm{Mg} 5 \%-\mathrm{La} 5 \% / \mathrm{ZnO}$, and (e) $\mathrm{Mg} 6 \%-\mathrm{La} 4 \% / \mathrm{ZnO}$ nanoparticles.

in bang gap by La doping may be attributed to the decrease in the particle size. According to XRD and TEM results, there is a noticeable decrease in the particle size of doped and co-doped nanoparticles. As the particle size decreases, the energy levels discrete and, eventually, the band gap energy increases. The increasing in the band gap energy and blue shift in the absorption edge by doping of La and $\mathrm{Mg}$ ions may be attributed to the Burstein-Moss effect. This effect is caused by the transition energy in degenerate nanoparticles according to the partial field conduction band [36, 77]. Furthermore, shift to lower wavelength or higher energy, blue shift, is due to decreasing the grain size [63]. The blue shift can be attributed to the quantum size effect in nanoparticles [29, 77], distortion of host lattice and defect generation [29]. Gopalakrishnan and Muthukumaran [29], found that increasing $\mathrm{ZnO}$ band gap with Ni doping may be due to sp-d spin exchange interaction between band electrons and localized spin of the transition metal ions. Osei-Bonsu Oppong et al. [78] argued that, since d-d transition is superior to sp-d transition, La doping in $\mathrm{ZnO}$ lattice enhances band gap energy. When
Table 4 Band gap energy and absorption edge for the prepared nanoparticles.

\begin{tabular}{lcl}
\hline Photocatalyst & $\mathrm{Eg}(\mathrm{eV})$ & $\lambda(\mathrm{nm})$ \\
\hline $\mathrm{ZnO}$ & 3.111 & 398.52 \\
$\mathrm{Mg} 5 \% / \mathrm{ZnO}$ & 3.183 & 389.51 \\
$\mathrm{La} 4 \% / \mathrm{ZnO}$ & 3.150 & 393.59 \\
$\mathrm{Mg} 6 \%-\mathrm{La} 4 \% / \mathrm{ZnO}$ & 3.175 & 390.49 \\
\hline
\end{tabular}

the band gap in the nanoparticles enlarges, the separation of the photo-induced electron-hole pairs occurs better [22].

\subsection{Photocatalytic Activity}

The main purpose of the study is to examine the photocatalytic activity of the prepared nanoparticles. The photocatalytic activity of the bare, doped and co-doped samples in the removal of RhB under UVA irradiation has been shown in Table 5. Blank tests results indicated that the removal percent of RhB by UVA alone (photolysis) and adsorption on nanoparticles was negligible.

The results, given in Table 5, obviously reveal that, as $\mathrm{Mg}$ doping increases up to $5 \mathrm{wt} \%$, RhB removal percent increases significantly. The photocatalytic activity of semiconductor nanoparticles is proportional with their band gap energy. That is, higher band gap energy corresponds with stronger electron-hole pairs which, consequently, lead to higher photocatalytic activity [4]. According to DRS results, Mg-doped $\mathrm{ZnO}$ has a larger band gap than bare $\mathrm{ZnO}$, which may account for the higher photocatalytic activity of doped samples. Moreover, the increased $\mathrm{Mg}$ dopant leads to more crystal deficiency. Crystal deficiency retards recombination of the electron-hole pair and leads to improved photocatalytic activity [4]. Xue et al. [79], reported that most $\mathrm{Mg}$ ions were substituted in the $\mathrm{Zn}$ sites of $\mathrm{ZnO}$, which resulted in an increase not only in $\mathrm{ZnO}$ band gap, but also in the quality of $\mathrm{ZnO}$ crystalline.

Prabu and Johnson [80] argued that the formation of intrinsic defects in the $\mathrm{ZnS}$ lattice is due to the incorporation of $\mathrm{Mg}^{2+}$.

However, $\mathrm{Mg}$ content values greater than 5 wt. \% decreased the photocatalytic activity of $\mathrm{ZnO}$ nanoparticles. Such a reduction is attributed to the aggregation of $\mathrm{Mg}$ dopant and the reduction of homogeneous distribution of dopant in the $\mathrm{ZnO}$ lattice [81]. As shown in Table 5, it is observed that photocatalytic activity significantly enhanced along with La doping up to 4 wt. \%. $\mathrm{La}^{3+}$ due to existence of a partially filled orbital effectively scavenges photoinduced electrons and produces unstable $\mathrm{La}^{2+}$ [82]. 


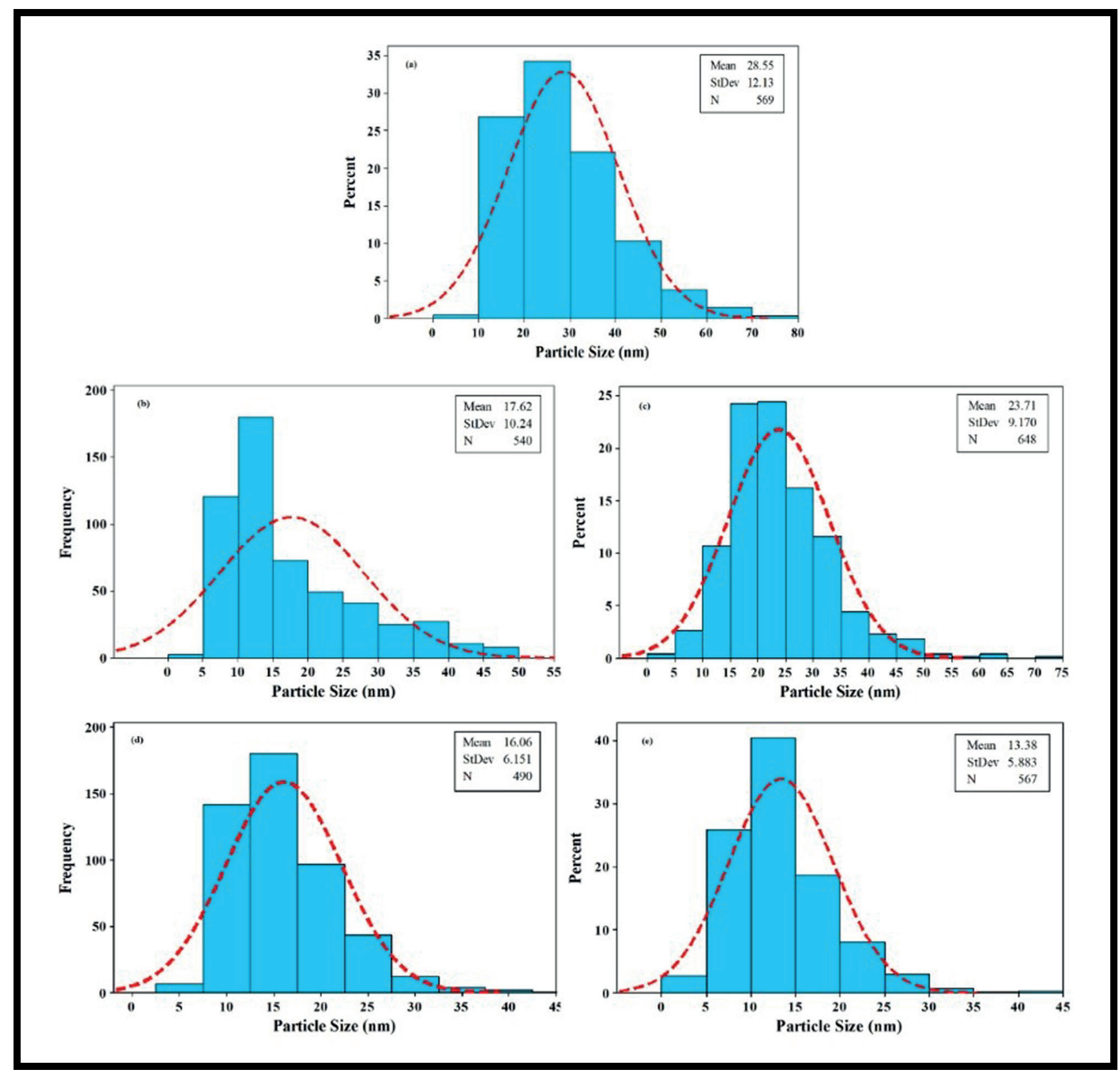

Fig. 5 Histograms of particles size distribution of (a) $\mathrm{ZnO}$, (b) $\mathrm{Mg} 5 \% / \mathrm{ZnO}$, (c) $\mathrm{La} 4 \% / \mathrm{ZnO}$, (d) $\mathrm{Mg} 5 \%-\mathrm{La} 5 \% / \mathrm{ZnO}$, and (e) $\mathrm{Mg} 6 \%$-La4\%/ZnO nanoparticles.
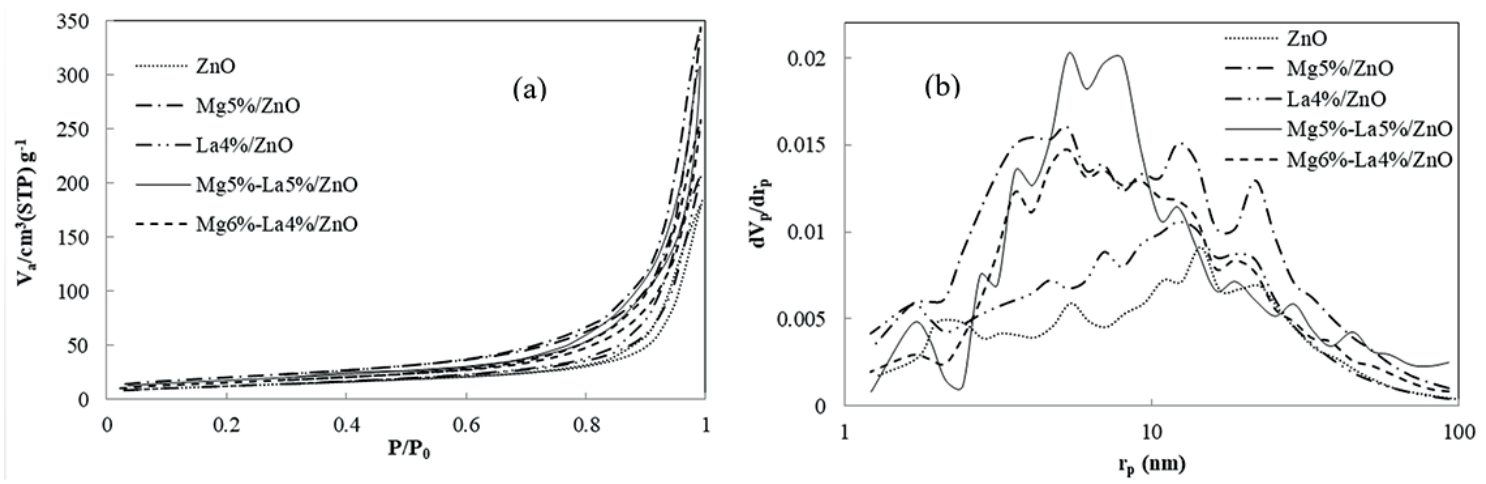

Fig. 6 Adsorption-desorption isotherm (a) and BJH diagrams (b) for prepared nanoparticles. 


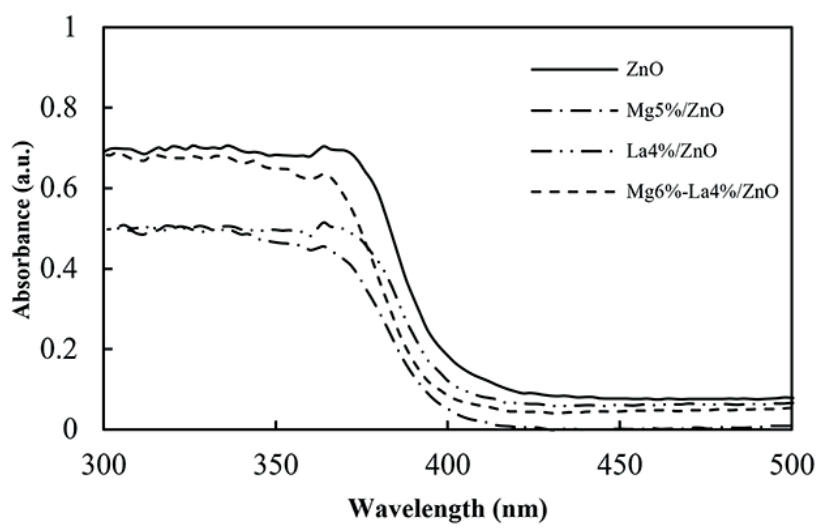

Fig. 7 The DRS-UV-Vis spectra for the prepared nanoparticles.

Table 5 The photocatalytic removal percent of RhB in the presence of

\begin{tabular}{lccc}
\multicolumn{4}{c}{ various catalysts. } \\
\hline Photocatalyst & Metal loading (wt. \%) & $\begin{array}{c}\text { Removal } \\
\text { percent }\end{array}$ \\
\hline bare $\mathrm{ZnO}$ & $\mathrm{Mg}$ & $\mathrm{La}$ & 55.40 \\
$\mathrm{Mg} / \mathrm{ZnO}$ & 0 & 0 & 58.83 \\
$\mathrm{Mg} / \mathrm{ZnO}$ & 1 & 0 & 60.10 \\
$\mathrm{Mg} / \mathrm{ZnO}$ & 2 & 0 & 63.07 \\
$\mathrm{Mg} / \mathrm{ZnO}$ & 3 & 0 & 65.07 \\
$\mathrm{Mg} / \mathrm{ZnO}$ & 4 & 0 & 83.18 \\
$\mathrm{Mg} / \mathrm{ZnO}$ & 5 & 0 & 81.96 \\
$\mathrm{La} / \mathrm{ZnO}$ & 6 & 0 & 77.77 \\
$\mathrm{La} / \mathrm{ZnO}$ & 0 & 1 & 81.96 \\
$\mathrm{La} / \mathrm{ZnO}$ & 0 & 2 & 83.87 \\
$\mathrm{La} / \mathrm{ZnO}$ & 0 & 3 & 85.18 \\
$\mathrm{La} / \mathrm{ZnO}$ & 0 & 4 & 75.38 \\
$\mathrm{La} / \mathrm{ZnO}$ & 0 & 5 & 71.89 \\
$\mathrm{Mg}-\mathrm{La} / \mathrm{ZnO}$ & 0 & 6 & 91.18 \\
$\mathrm{Mg}-\mathrm{La} / \mathrm{ZnO}$ & 5 & 5 & 89.18 \\
\hline & 6 & 4 &
\end{tabular}

In air-equilibrated system, electron discharges into the dissolved oxygen to form the $\mathrm{O}_{2}^{-\circ}$ and ${ }^{\circ} \mathrm{OH}$ as follows:

$$
\begin{aligned}
& \mathrm{O}_{2}+e_{C B}^{-} \rightarrow \mathrm{O}_{2}^{-\circ}, \\
& \mathrm{O}_{2}+H^{+}+e_{C B}^{-} \rightarrow \mathrm{HO}_{2}^{\circ}, \\
& \mathrm{O}_{2}+2 \mathrm{H}^{+}+2 e_{C B}^{-} \rightarrow \mathrm{H}_{2} \mathrm{O}_{2} .
\end{aligned}
$$

In addition, $\mathrm{HO}_{2}^{\circ}$ and $\mathrm{O}_{2}^{-\circ}$ react with each other to produce $\mathrm{H}_{2} \mathrm{O}_{2}$ according to Eq. (6):

$$
\mathrm{HO}_{2}^{\circ}+\mathrm{O}_{2}^{-\circ}+\mathrm{H}^{+} \rightarrow \mathrm{H}_{2} \mathrm{O}_{2}+\mathrm{O}_{2} \text {. }
$$

The produced $\mathrm{H}_{2} \mathrm{O}_{2}$ in Eqs. (5), (6) reacts with photoinduced electrons which lead to the production of hydroxyl radicals (Eq. (7)). Hydroxyl radicals can effectively participate non-selectively in the degradation of target molecules.

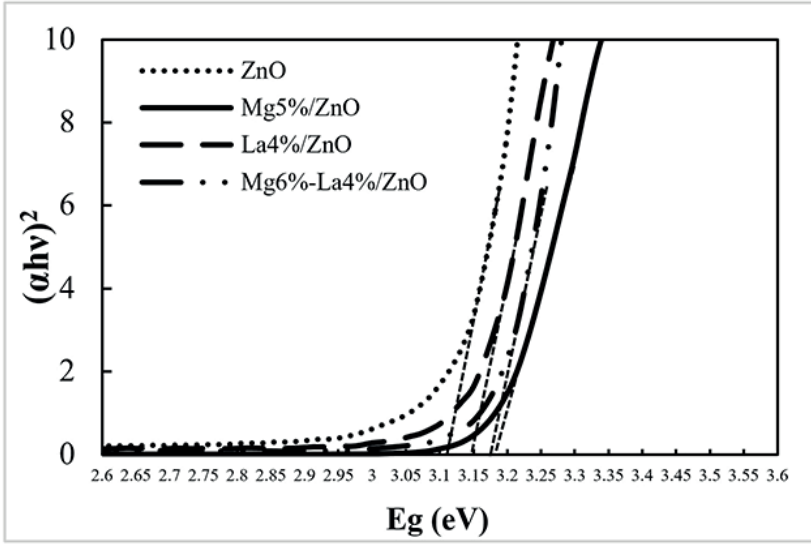

Fig. 8 Tauc plot and band gap energy estimation for the prepared nanoparticles.

$$
\mathrm{H}_{2} \mathrm{O}_{2}+\mathrm{H}^{+}+e_{\mathrm{CB}}^{-} \rightarrow \mathrm{H}_{2} \mathrm{O}+{ }^{\circ} \mathrm{OH} \text {. }
$$

Jia et al. [77], found that La doping produces surface defects and a space charge layer in the surface of La-doped $\mathrm{ZnO}$ samples, which hinders recombination of photoinduced electron - hole pairs. However, when the La amount exceeds 4 wt. \%, the photocatalytic activity is notably reduced which is attributed to the aggregation of $\mathrm{La}_{2} \mathrm{O}_{3}$ and to the negative impact of surface charge layer [77]. Covering $\mathrm{ZnO}$ surface from light absorption at higher doping values is another reason for decreasing photocatalytic activity [65]. Tayade et al. [83], maintained that ions with an ionic radius higher than the host element occupy the interstitial positions; however, ions with an ionic radius near the host element occupy the substitutional positions. Also, they found that the occupation of interstitial positions is more effective in the photocatalytic activity than the occupation of the substitutional positions. In the present study, $\mathrm{La}^{3+}$ ions have an ionic radius which is greater than that of the host element $\left(\mathrm{Zn}^{2+}\right)$; nevertheless, $\mathrm{Mg}^{2+}$ ions have an ionic radius which is close to that of $\mathrm{Zn}^{2+}$ ions. Therefore, $\mathrm{La}^{3+}$ and $\mathrm{Mg}^{2+}$ ions are expected to occupy interstitial and substitutional positions in $\mathrm{ZnO}$ lattice, respectively. That is why La-doped $\mathrm{ZnO}$ has higher photocatalytic activity up to $4 \%$ (La optimum percent) than Mg-doped $\mathrm{ZnO}$. According to the results given in Table 5, co-doped Mg-La/ $\mathrm{ZnO}$ has higher photocatalytic activity than mono-doped and bare $\mathrm{ZnO}$. The higher photocatalytic activity of the co-doped $\mathrm{Mg}-\mathrm{La} / \mathrm{ZnO}$ may be due to different sites of $\mathrm{La}^{3+}$ and $\mathrm{Mg}^{2+}$ ions in $\mathrm{ZnO}$ lattice so that $\mathrm{La}^{3+}$ in the interstitial positions and $\mathrm{Mg}^{2+}$ in the substitutional positions. On the other hand, $\mathrm{Mg}$ doping increases band gap and $\mathrm{ZnO}$ surface area. Consequently, the increased band gap has a critical impact on photocatalytic activity. Firstly, a catalyst with a wide band gap absorbs less light. Due to the 
emission wavelength of the lamp $(365 \mathrm{~nm})$, the reduced light absorption is not important in this study. According to Table 4, all catalysts can absorb wavelengths less than $390 \mathrm{~nm}$. Secondly, a wider band gap corresponds with better separation and also with stronger photoinduced electron-hole pairs. Thus, it can be argued that a wider band gap improves photocatalytic activity. Increasing the specific surface area with $\mathrm{Mg}$ doping is another important factor for higher photocatalytic activity. A higher specific surface area enhances RhB adsorption and active sites, which, consequently, have notable positive impacts on photocatalytic activity. In addition, La with partially filled orbital and a space charge layer in the surface scavenges photoinduced electrons and enhances photocatalytic activity.

\section{Conclusion}

In this study, $\mathrm{Mg}$ and $\mathrm{La}$ doped and co-doped $\mathrm{ZnO}$ nanoparticles were successfully prepared by the sol-gel method. The XRD results of nanoparticles did not show

\section{References}

[1] Baruah, S., Pal, S. K., Dutta, J. "Nanostructured Zinc Oxide for Water Treatment", Nanoscience and Nanotechnology-Asia, 2(2), pp. 90-102, 2012.

https://doi.org/10.2174/2210681211202020090

[2] Han, F., Kambala, V. S. R., Srinivasan, M., Rajarathnam, D., Naidu, R. "Tailored Titanium Dioxide Photocatalysts for the Degradation of Organic Dyes in Wastewater Treatment: A Review", Applied Catalysis A: General, 359(1-2), pp. 25-40, 2009. https://doi.org/10.1016/j.apcata.2009.02.043

[3] Alfano, O. M., Bahnemann, D., Cassano, A. E., Dillert, R., Goslich, R. "Photocatalysis in Water Environments Using Artificial and Solar light", Catalysis Today, 58(2-3), pp. 199-230, 2000. https://doi.org/10.1016/S0920-5861(00)00252-2

[4] Zarei, N., Behnajady, M. A. "Synthesis, Characterization, and Photocatalytic Activity of Sol-gel Prepared Mg/ZnO Nanoparticles", Desalination and Water Treatment, 57(36), pp. 1-7, 2015. https://doi.org/10.1080/19443994.2015.1083479

[5] Khataee, A., Karimi, A., Arefi-Oskoui, S., Darvish, R., Hanifehpour, Y., Soltani, B., Joo, S. W. "Sonochemical Synthesis of Pr-doped ZnO Nanoparticles for Sonocatalytic Degradation of Acid Red 17", Ultrasonics Sonochemistry, 22, pp. 371-381, 2015. https://doi.org/10.1016/j.ultsonch.2014.05.023

[6] Modirshahla, N., Behnajady, M. A., Mohammadi-Aghdam, S. "Investigation of the effect of different electrodes and their connections on the removal efficiency of 4-nitrophenol from aqueous solution by electrocoagulation", Journal of Hazardous Materials, 154, pp. 778-786, 2008. https://doi.org/10.1016/j.jhazmat.2007.10.120

[7] Ahmad, M., Ahmed, E., Hong, Z. L., Ahmed, W., Elhissi, A., Khalid, N. R. "Photocatalytic, Sonocatalytic and Sonophotocatalytic Degradation of Rhodamine B Using ZnO/CNTs Composites Photocatalysts", Ultrasonics Sonochemistry, 21(2), pp. 761-773, 2014. https://doi.org/10.1016/j.ultsonch.2013.08.014 the presence of separate metal oxide diffraction peaks for $\mathrm{Mg}$ and $\mathrm{La}$ phases due to the proper incorporation of doped ions. The FESEM, EDX and TEM results confirmed that all the prepared nanoparticles had a uniform spherical-like morphology with a homogenous distribution; however, the grain size of the nanoparticles decreased due to the doping and co-doping processes. The DRS results indicated a significant increase in $\mathrm{Eg}$ for $\mathrm{Mg}$ and $\mathrm{La}$ doped and co-doped $\mathrm{ZnO}$ nanoparticles. $\mathrm{N}_{2}$ adsorption-desorption results indicated an increase in BET surface area and pore volume for doped and co-doped $\mathrm{ZnO}$ nanoparticles. $\mathrm{Mg} 5 \%-\mathrm{La} 5 \% / \mathrm{ZnO}$ had the highest capability for photocatalytic $\mathrm{RhB}$ removal in comparison with mono-doped and bare $\mathrm{ZnO}$.

\section{Acknowledgments}

The authors would like to gratefully acknowledge the supports of Islamic Azad University, North Tehran Branch and Ardabil Branch.

[8] Xiao, J., Xie, Y., Cao, H., Nawaz, F., Zhang, S., Wang, Y. "Disparate Roles of Doped Metal Ions in Promoting Surface Oxidation of $\mathrm{TiO}_{2}$ Photocatalysis", Journal of Photochemistry and Photobiology A: Chemistry, 315, pp. 59-66, 2016. https://doi.org/10.1016/j.jphotochem.2015.09.013

[9] Chatterjee, D., Dasgupta, S. "Visible Light Induced Photocatalytic Degradation of Organic Pollutants", Journal of Photochemistry and Photobiology C: Photochemistry Reviews, 6(2-3), pp. 186$205,2005$. https://doi.org/10.1016/j.jphotochemrev.2005.09.001

[10] Segne, T. A., Tirukkovalluri, S. R., Challapalli, S. "Studies on Characterization and Photocatalytic Activities of Visible Light Sensitive $\mathrm{TiO}_{2}$ Nanocatalysts co-doped with Magnesium and Copper", International Research Journal of Pure and Applied Chemistry, 1, pp. 84-103, 2011. https://doi.org/10.9734/IRJPAC/2011/453

[11] Eren, Z., Ince, N. H. "Sonolytic and Sonocatalytic Degradation of Azo Dyes by Low and High Frequency Ultrasound", Journal of Hazardous Materials, 177(1-3), pp. 1019-1024, 2010. https://doi.org/10.1016/j.jhazmat.2010.01.021

[12] Bokhale, N. B., Bomble, S. D., Dalbhanjan, R. R., Mahale, D. D., Hinge, S. P., Banerjee, B. S., Mohod, A. V., Gogate, P. R. "Sonocatalytic and Sonophotocatalytic Degradation of Rhodamine 6G Containing Wastewaters", Ultrasonics Sonochemistry, 21(5), pp. 1797-1804, 2014. https://doi.org/10.1016/j.ultsonch.2014.03.022

[13] Rauf, M.A., Meetani, M.A., Hisaindee, S. "An Overview on the Photocatalytic Degradation of Azo Dyes in the Presence of $\mathrm{TiO}_{2}$ Doped with Selective Transition Metals", Desalination, 276(1-3), pp. 13-27, 2011.

https://doi.org/10.1016/j.desal.2011.03.071 
[14] Behnajady, M. A., Tohidi, Y. "Synthesis, Characterization and Photocatalytic Activity of Mg-impregnated $\mathrm{ZnO}-\mathrm{SnO}_{2}$ Coupled Nanoparticles", Photochemistry and Photobiology, 90(1), pp. 51-56, 2014.

https://doi.org/10.1111/php.12164

[15] Choina, J., Dolat, D., Kusiak, E., Janus, M., Morawski, A. W. "TiO Modified by Ammonia as a Long Lifetime Photocatalyst for Dyes Decomposition", Polish Journal of Chemical Technology, 11(4), pp. 1-6, 2009.

https://doi.org/10.2478/v10026-009-0035-9

[16] Lodha, S., Jain, A., Punjabi, P. B. "A Novel Route for Waste Water Treatment: Photocatalytic Degradation of Rhodamine B", Arabian Journal of Chemistry, 4(4), pp. 383-387, 2011.

https://doi.org/10.1016/j.arabjc.2010.07.008

[17] Abdollahi, Y., Zakaria, A., Abbasiyannejad, M., Masoumi, H. R. F., Moghaddam, M. G., Matori, K. A., Jahangirian, H., Keshavarzi, A. "Artificial Neural Network Modeling of p-Cresol Photodegradation", Chemistry Central Journal, 96(7), pp. 1-7, 2013.

https://doi.org/10.1186/1752-153X-7-96

[18] Zouaghi, R., David, B., Suptil, J., Djebbar, K., Boutiti, A., Guittonneau, S. "Sonochemical and Sonocatalytic Degradation of Monolinuron in Water", Ultrasonics Sonochemistry, 18(5), pp. 1107-1112, 2011.

https://doi.org/10.1016/j.ultsonch.2011.03.008

[19] Behnajady, M. A., Modirshahla, N., Shokri, M., Zeininezhad, A., Zamani, H. A. "Enhancement Photocatalytic Activity of $\mathrm{ZnO}$ Nanoparticles by Silver Doping with Optimization of Photodeposition Method Parameters", Journal of Environmental Science and Health, Part A, 44(7), pp. 666-672, 2009. https://doi.org/10.1080/10934520902847752

[20] Ghaly, M. Y., Ali, M. E. M., Osterlund, L., Khattab, I. A., Badawy, M. I., Farah, J. Y., Zaher, F. M., Al-Maghrabi, M. N. عZnO/spiral-shaped Glass for Solar Photocatalytic Oxidation of Reactive Red120", Arabian Journal of Chemistry, 10(2), pp. S3501-S3507, 2017.

https://doi.org/10.1016/j.arabjc.2014.02.015

[21] Behnajady, M. A., Eskandarloo, H. "Silver and Copper Co-impregnated onto $\mathrm{TiO}_{2}-\mathrm{P} 25$ Nanoparticles and its Photocatalytic Activity", Chemical Engineering Journal, 228(15), pp. 1207-1213, 2013. https://doi.org/10.1016/j.cej.2013.04.110

[22] Eskandarloo, H., Badiei, A., Behnajady, M. A., Ziarani, G. M. "Ultrasonic-assisted Degradation of Phenazopyridine with a Combination of Sm-doped $\mathrm{ZnO}$ Nanoparticles and Inorganic Oxidants", Ultrasonics Sonochemistry, 28, pp. 169-177, 2016. https://doi.org/10.1016/j.ultsonch.2015.07.012

[23] Lee, S. D., Nam, S-H., Kim, M-H., Boo, J-H. "Synthesis and Photocatalytic Property of ZnO Nanoparticles Prepared by Spraypyrolysis Method", Physics Procedia, 32, pp. 320-326, 2012. https://doi.org/10.1016/j.phpro.2012.03.563

[24] Al-Owais, A. A. "Synthesis and Magnetic Properties of Hexagonally Packed $\mathrm{ZnO}$ Nanorods", Arabian Journal of Chemistry, 6(2), pp. 229-234, 2013. https://doi.org/10.1016/j.arabjc.2011.11.001
[25] Cuevas, A. G., Balangcod, K., Balangcod, T., Jasmin, A. "Surface Morphology, Optical Properties and Antibacterial Activity of Zinc Oxide Films Synthesized via Spray Pyrolysis", Procedia Engineering, 68, pp. 537-543, 2013. https://doi.org/10.1016/j.proeng.2013.12.218

[26] Anandan, S., Vinu, A., Mori, T., Gokulakrishnan, N., Srinivasu, P., Murugesan, V., Ariga, K. "Photocatalytic Degradation of 2,4,6-Trichlorophenol Using Lanthanum Doped $\mathrm{ZnO}$ in Aqueous Suspension", Catalysis Communications, 8(9), pp. 1377-1382, 2007. https://doi.org/10.1016/j.catcom.2006.12.001

[27] Kaneva, N. V., Dushkin, C. D. "Preparation of Nanocrystalline Thin Films of $\mathrm{ZnO}$ by Sol-gel Dip Coating", Bulgarian Chemical Communications, 43(2), pp. 259-263, 2011. [online] Available at: http://www.bgcryst.com/symp10/proceeding/12 Kaneva_259-263.pdf [Accessed: 06 August 2018]

[28] Sivakumar, K., Kumar, V. S., Muthukumarasamy, N., Thambidurai, M., Senthil, T. S. "Influence of $\mathrm{pH}$ on $\mathrm{ZnO}$ Nanocrystalline Thin Films Prepared by Sol-gel Dip Coating Method", Bulletin of Materials Science, 35(3), pp. 327-331, 2012. https://doi.org/10.1007/s12034-012-0305-7

[29] Gopalakrishnan, R., Muthukumaran, S. "Nanostructure, Optical and Photoluminescence Properties of $\mathrm{Zn}_{1-\mathrm{X}} \mathrm{Ni}_{\mathrm{X}} \mathrm{O}$ Nanoclusters by Co-Precipitation Method", Journal of Materials Science: Materials in Electronics, 24(4), pp. 1069-1080, 2013. https://doi.org/10.1007/S10854-012-0882-7

[30] Chauhan, R., Kumar, A., Chaudhary, R. P. "Synthesis and Characterization of Silver Doped ZnO Nanoparticles", Archives of Applied Science Research, 2(5), pp. 378-385, 2010. [online] Available at: https://www.scholarsresearchlibrary.com/articles/ synthesis-and-characterization-of-silver-doped-zno-nanoparticles.pdf [Accessed: 07 August 2018]

[31] Young, S. J., Ji, L. W., Chang, S. J., Liang, S. H., Lam, K. T., Fang, T. H., Chen, K. J., Du, X. L., Xue, Q. K. "ZnO-based MIS Photodetectors", Sensors and Actuators A:Physical, 141(1), pp. 225-229, 2008. https://doi.org/10.1016/j.sna.2007.06.003

[32] Ni, G., Chen, Y., Liu, Y., Liu, H., Zhang, Z. "Fabrication of ZnO Nanoparticles for Photocatalytic Reduction of $\mathrm{CO}_{2}$ ", MATEC Web of Conferences, 67, ID 02009, 2016. https://doi.org/10.1051/matecconf/20166702009

[33] Han, J., Liu, Y., Singhal, N., Wang, L., Gao, W. "Comparative Photocatalytic Degradation of Estrone in Water by $\mathrm{ZnO}$ and $\mathrm{TiO}_{2}$ under Artificial UVA and Solar Irradiation", Chemical Engineering Journal, 213(1), pp. 150-162, 2012. https://doi.org/10.1016/j.cej.2012.09.066

[34] Eskandarloo, H., Badiei, A., Behnajady, M. A., Ziarani, G. M. "Ultrasonic-assisted Sol-gel Synthesis of Samarium, Cerium Co-doped $\mathrm{TiO}_{2}$ Nanoparticles with Enhanced Sonocatalytic Efficiency", Ultrasonics Sonochemistry, 26, pp. 281-292, 2015. https://doi.org/10.1016/j.ultsonch.2015.02.001

[35] Georgekutty, R., Seery, M. K., Pillai, S. C. "A Highly Efficient Ag-ZnO Photocatalyst: Synthesis, Properties, and Mechanism", The Journal of Physical Chemistry C, 112(35), pp. 13563-13570, 2008.

https://doi.org/10.1021/jp802729a 
[36] Bloh, J. Z., Dillert, R., Bahnemann, D. W. "Transition MetalModified Zinc Oxides for UV and Visible Light Photocatalysis", Environmental Science and Pollution Research, 19(9), pp. 36883695, 2012.

https://doi.org/10.1007/s11356-012-0932-y

[37] Safaei-Ghomi, J., Ghasemzadeh, M. A. "Zinc Oxide Nanoparticle Promoted Highly Efficient One Pot Three-component Synthesis of 2,3-Disubstituted Benzofurans", Arabian Journal of Chemistry, 10(2), pp. S1774-S1780, 2017.

https://doi.org/10.1016/j.arabjc.2013.06.030

[38] Rajendran, S., Mansoob Khan, M., Gracia, F., Qin, J., Gupta. V. K., Arumainathan, S. "Ce ${ }^{3+}$ ion-induced visible-light photocatalytic degradation and electrochemical activity of $\mathrm{ZnO} / \mathrm{CeO}_{2}$ nanocomposite", Scientific Reports, 6(1), pp. 1-11, 2016.

https://doi.org/10.1038/srep31641

[39] Saravanan, R., Mansoob Khan, M., Gupta, V.K., Mosquera, E., Gracia, F., Narayanan, V., Stephen, A. "ZnO/Ag/ $\mathrm{Mn}_{2} \mathrm{O}_{3}$ nanocomposite for visible light-induced industrial textile effluent degradation, uric acid and ascorbic acid sensing and antimicrobial activity", RSC Advances, 5(44) pp. 34645-34651, 2015. https://doi.org/10.1039/C5RA02557E

[40] Saravanan, R., Karthikeyan, N., Gupta, V.K., Thirumal, E., Thangadurai, P., Narayanan, V., Stephen, A. "ZnO/Ag nanocomposite: An efficient catalyst for degradation studies of textile effluents under visible light", Materials Science \& Engineering: C, Materials for Biological Applications, 33(4), pp. 2235-2244, 2013. https://doi.org/10.1016/j.msec.2013.01.046

[41] Saravanan, R., Gupta, V. K., Prakash, T., Narayanan, V., Stephen, A. "Synthesis, Characterization and Photocatalytic Activity of Novel $\mathrm{Hg}$ doped $\mathrm{ZnO}$ Nanorods prepared by Thermal Decomposition Method", Journal of Molecular Liquids, 178, pp. 88-93, 2013. https://doi.org/10.1016/j.molliq.2012.11.012

[42] Saravanan, R., Gracia, F., Mansoob Khan, M., Poornima, Gupta, V. K., Narayanan, V., Stephen., A. "ZnO/CdO nanocomposites for textile effluent degradation and electrochemical detection", Journal of Molecular Liquids, 209, pp. 374-380, 2015. https://doi.org/10.1016/j.molliq.2015.05.040

[43] Saravanan, R., Gupta, V.K., Narayanan, V., Stephen, A. "Visible light degradation of textile effluent using novel catalyst $\mathrm{ZnO} / \gamma$ $\mathrm{Mn}_{2} \mathrm{O}_{3}$ ", Journal of the Taiwan Institute of Chemical Engineers, 45 (4), pp. 1910-1917, 2014. https://doi.org/10.1016/j.jtice.2013.12.021

[44] Saravanan, R., Gupta, V. K., Mosquera, E., Gracia, F. "Preparation and characterization of $\mathrm{V}_{2} \mathrm{O}_{5} / \mathrm{ZnO}$ nanocomposite system for photocatalytic application", Journal of Molecular Liquids, 198, pp. 409-412, 2014.

https://doi.org/10.1016/j.molliq.2014.07.030

[45] Saravanan, R., Karthikeyan, S., Gupta, V.K., Sekaran, G., Narayanan, V., Stephen, A. "Enhanced photocatalytic activity of $\mathrm{ZnO} / \mathrm{CuO}$ nanocomposite for the degradation of textile dye on visible light illumination", Materials Science \& Engineering: C, Materials for Biological Applications, 33(1), pp. 91-98, 2013. https://doi.org/10.1016/j.msec.2012.08.011

[46] Thaweesaeng, N., Supankit, S., Techidheera, W., Pecharapa, W. "Structure Properties of As-synthesized Cu-doped $\mathrm{ZnO}$ Nanopowder Synthesized by Co-Precipitation Method", Energy Procedia, 34, pp. 682-688, 2013.

https://doi.org/10.1016/j.egypro.2013.06.800
[47] Sankara, R. B., Venkatramana, R. S., Koteeswara, R. N., Pramoda, K. J. "Synthesis, Structural, Optical Properties and Antibacterial Activity of co-doped (Ag, Co) ZnO Nanoparticles", Research Journal of Material Sciences, 1(1), pp.11-20, 2013. [online] Available at: http://www.isca.in/MATERIAL_SCI/Archive/v1/ 11/3.ISCA-RJMatS-2013-003.pdf [Accessed: 07 August 2018]

[48] Anand, M., Shim, H-S., Kim, Y. S., Kim, W. B. "Structural and Optical Properties of Co- and Ti-ZnO Composite Nanofibers Prepared by Using an Electrospinning Method", Journal of the Korean Physical Society, 53, pp. 2423-2426, 2008. https://doi.org/10.3938/jkps.53.2423

[49] Cao, H. T., Pei, Z. L., Gong, J., Sun, C., Huang, R. F., Wen, L. S. "Transparent Conductive Al and Mn Doped $\mathrm{ZnO}$ Thin Films Prepared by DC Reactive Magnetron Sputtering", Surface and Coatings Technology, 184(1), pp. 84-92, 2004. https://doi.org/10.1016/j.surfcoat.2003.09.046

[50] Chongsri, K., Bangbai, C., Techitdheera, W., Pecharapa, W. "Characterization and Photoresponse Properties of Sn-doped $\mathrm{ZnO}$ Thin Films", Energy Procedia, 34, pp. 721-727, 2013. https://doi.org/10.1016/j.egypro.2013.06.805

[51] Dakhel, A. A., El-Hilo, M. "Ferromagnetic Nanocrystalline Gd-doped ZnO Powder Synthesized by Coprecipitation", Journal of Applied Physics, 107(12), ID: 123905-6, 2010. https://doi.org/10.1063/1.3448026

[52] Ali, A. M., Muhammad, A., Shafeeq, A., Asghar, H. M. A., Hussain, S. N., Sattar, H. "Doped Metal Oxide $(\mathrm{ZnO})$ and Photocatalysis: A Review", Journal of Pakistan Institute of Chemical Engineers, 40(1), pp. 11-19, 2012. [online] Available at: http://piche.org.pk/journal/index.php?journal=jpiche\&page=article\&op=view\&path\%5B\%5D=52 [Accessed: 07 August 2018]

[53] Benelmadjat, H., Boudine, B., Keffous, A., Gabouze, N. "Photoresponse and $\mathrm{H}_{2}$ Gas Sensing Properties of Highly Oriented Al and Al/Sb Doped ZnO Thin Films", Progress in Natural Science: Materials International, 23(6), pp. 519-523, 2013. https://doi.org/10.1016/j.pnsc.2013.11.001

[54] Zhang, W., Zhao, J., Liu, Z., Liu, Zh. "Structural, Optical and Magnetic Properties of $\mathrm{Zn}_{1-\mathrm{X}} \mathrm{Fe}_{\mathrm{X}} \mathrm{O}$ Powders by Sol-gel Method", Applied Surface Science, 284, pp. 49-52, 2013. https://doi.org/10.1016/j.apsusc.2013.06.163

[55] Pillai, S. C., Kelly, J. M., Ramesh, R., Mccormach, D. E. "Advances in the Synthesis of $\mathrm{ZnO}$ Nanomaterials for Varistor Devices", Journal of Materials Chemistry C, 1(20), pp. 3268-3281, 2013. https://doi.org/10.1039/c3tc00575e

[56] Behnajady, M. A., Alizade, B., Modirshahla, N. "Synthesis of Mg-Doped $\mathrm{TiO}_{2}$ Nanoparticles under Different Conditions and its Photocatalytic Activity", Photochemistry and Photobiology, 87(6), pp. 1308-1314, 2011 https://doi.org/10.1111/j.1751-1097.2011.01002.x

[57] Feng, H., Yu, L. E., Zhang, M. H., Zakaria, M. H. "Ultrasonic Synthesis and Photocatalytic Performance of Metal-Ions Doped $\mathrm{TiO}_{2}$ Catalysts under Solar Light Irradiation", Materials Research Bulletin, 48(2), pp. 672-681, 2013. https://doi.org/10.1016/j.materresbull.2012.11.027

[58] Wang, H., Baek, S., Lee, J., Lim, S. "High Photocatalytic Activity of Silver-Loaded $\mathrm{ZnO}-\mathrm{SnO}_{2}$ Coupled Catalyst", The Chemical Engineering Journal, 146(3), pp. 355-361, 2009.

https://doi.org/10.1016/j.cej.2008.06.016 
[59] Lee, M.-I., Huang, M.-C., Legrand, D., Lerondel, G., Lin, J.-C. "Structure and characterization of Sn, Al co-doped zinc oxide thin films prepared by sol-gel dip-coating process", Thin Solid Films, 570B, pp. 516-526, 2014. https://doi.org/10.1016/j.tsf.2014.04.051

[60] Tian, X., Pan, Z., Zhang, H., Fan, H., Zeng, X., Xiao, C., Hu, G., Wei, Z. "Growth and characterization of the Al-doped and Al-Sn co-doped $\mathrm{ZnO}$ nanostructures", Ceramics International, 39(6), pp. 6497-6502, 2013.

https://doi.org/10.1016/j.ceramint.2013.01.081

[61] Aksoy, S., Caglar, Y.Y., Ilican, S., Caglar, M. "Sol-gel derived Li-Mg co-doped $\mathrm{ZnO}$ films: preparation and characterization via XRD, XPS, FESEM", Journal of Alloys and Compounds, 512(1), pp. 171-178, 2012.

https://doi.org/10.1016/j.jallcom.2011.09.058

[62] Talat-Mehrabad, J., khosravi, M., Modirshahla, N., Behnajady, M. A. "Sol-gel Preparation and Characterization of $\mathrm{Ag}$ and $\mathrm{Mg}$ Co-doped Nano $\mathrm{TiO}_{2}$ : Efficient Photocatalytic Degradation of C.I. Acid Red 27", Research on Chemical Intermediates, 42(2), pp. 595-609, 2016.

https://doi.org/10.1007/S11164-015-2044-Z

[63] Suwanboon, S. "Structural and Optical Properties of Nanocrystalline ZnO Powder from Sol-gel Method", Science Asia, 34, pp. 31-34, 2008. https://doi.org/10.2306/scienceasia1513-1874.2008.34.031

[64] Patterson, A. L. "The Scherrer Formula for X-Ray Particle Size Determination", Physical Review Journals Archive, 56, pp. 978982, 1939 .

https://doi.org/10.1103/PhysRev.56.978

[65] Reza, W., Bahnemann, D., Muneer, M. "A Green Approach for Degradation of Organic Pollutants Using Rare Earth Metal Doped Bismuth Oxide", Catalysis Today, 300, pp. 89-98, 2018. https://doi.org/10.1016/j.cattod.2017.07.029

[66] Vignesh, K., Rajarajan, M., Suganthi, A. "Visible Light Assisted Photocatalytic Performance of $\mathrm{Ni}$ and $\mathrm{Th}$ Co-doped $\mathrm{ZnO}$ Nanoparticles for the Degradation of Methylene Blue Dye", Journal of Industrial and Engineering Chemistry, 20(5), pp. 38263833, 2014.

https://doi.org/10.1016/J.Jiec.2013.12.086

[67] Mehta, S. K., Kumar, S., Chavdhary, S., Bhasin, K. K. "Nucleation and Growth of Surfactant Passivated CdS and HgS NPs: Time Dependent Absorption and Luminescence Profiles", Supplementary Material for Nanoscale, Royal Society of Chemistry, 2, pp. 145152, 2010.

https://doi.org/10.1039/B9NR00070D

[68] Evingur, G. A., Pekcan, O. "Optical Energy Band Gap of PAAm-GO Composites", Composite Structures, 183, pp. 212-215, 2018.

https://doi.org/10.1016/j.compstruct.2017.02.058

[69] Chand, P., Gaur, A., Kumar, A. "Structural and Optical Properties of ZnO Nanoparticles Synthesizes at Different pH Values", Journal of Alloys and Compounds, 539, pp. 174-178, 2012. https://doi.org/10.1016/j.jallcom.2012.05.104
[70] Feroz, A. M. "Transparent Wide Band Gap Crystals Follow Indirect Allowed Transition and Bipolaron Hopping Mechanism", Results in Physics, 4, pp.103-104, 2014. https://doi.org/10.1016/j.rinp.2014.06.001

[71] Wang, J., Gao, L. "Photoluminescence Properties of Nanocrystalline $\mathrm{ZnO}$ Ceramics Prepared by Pressureless Sintering and Spark Plasma Sintering", Journal of the American Ceramic Society, 88(6), pp. 1637-1639, 2005. https://doi.org/10.1111/j.1551-2916.2005.00259.x

[72] Shirdel, B., Behnajady, M. A. "Sol-gel Synthesis of Ba-doped $\mathrm{ZnO}$ Nanoparticles with Enhanced Photocatalytic Activity in Degrading Rhodamine B under UV-A Irradiation", International Journal for Light and Electron Optics, 147, pp. 143-150, 2017. https://doi.org/10.1016/j.ijleo.2017.08.059

[73] Mahyar, A., Behnajady, M. A., Modirshahla, N. "Characterization and Photocatalytic Activity of $\mathrm{SiO}_{2}-\mathrm{TiO}_{2}$ Mixed Oxide Nanoparticles Prepared by Sol-gel Method", Indian Journal of Chemistry, 49(12), pp. 1593-1600, 2010. [online] Available at: https://pdfs.semanticscholar.org/9220/7f72500895fc1b79bbfc495ac83abaabc12f.pdf [Accessed: 07 August 2018]

[74] Mahmoudi, E., Behnajady, M. A. "Synthesis of $\mathrm{Fe}_{3} \mathrm{O}_{4} \mathrm{NiO}$ Core-Shell Nanocomposite by the Precipitation Method and Investigation of $\mathrm{Cr}(\mathrm{VI})$ Adsorption Efficiency", Colloids and Surfaces A: Physicochemical and Engineering Aspects, 538, pp. 287-296, 2018.

https://doi.org/10.1016/j.colsurfa.2017.11.020

[75] Talat-Mehrabad, J., Khosravi, M., Modirshahla, N., Behnajady, M. A. "Synthesis, Characterization, and Photocatalytic Activity of co-Doped $\mathrm{Ag}$-, $\mathrm{Mg}^{-\mathrm{TiO}_{2}}-\mathrm{P} 25$ by Photodeposition and Impregnation Methods", Desalination and Water Treatment, 57(22), pp. 1-11, 2015. https://doi.org/10.1080/19443994.2015.1036780

[76] Chakma, S., Moholkar, V. S. "Investigation in Mechanistic Issues of Sonocatalysis and Sonophotocatalysis Using Pure and Doped Photocatalysts", Ultrasonics Sonochemistry, 22, pp. 287-299, 2015. https://doi.org/10.1016/j.ultsonch.2014.06.008

[77] Jia, T., Wang, W., Long, F., Fu, Z., Wang, H., Zhang, Q. "Fabrication, Characterization and Photocatalytic Activity of La-doped ZnO Nanowires", Journal of Alloys and Compounds, 484(1-2), pp. 410-415, 2009.

https://doi.org/10.1016/j.jallcom.2009.04.153

[78] Oppong, S. O-B., Anku, W. W., Opoku, F., Shukla, S. K., Govender, P. P. "Photodegradation of Eosin Yellow Dye in Water under Simulated Solar Light Irradiation Using La-Doped $\mathrm{ZnO}$ Nanostructure Decorated on Graphene Oxide as an Advanced Photocatalyst", Materials Science inc. Nanomaterials and Polymers, 3(4), pp. 1180-1188, 2018. https://doi.org/10.1002/slct.201702470

[79] Xue, L., Xaing, L., Ting, L. P., Wang, C. X., Ying, L., Bao, C. C. "Mg Doping Reduced Full Width at Half Maximum of the Nearband-edge Emission in Mg Doped ZnO Films", Chinese Physics B, 19(2), ID: 027202, 2010.

https://doi.org/10.1088/1674-1056/19/2/027202 
74 Khanizadeh et al.

Period. Polytech. Chem. Eng., 64(1), pp. 61-74, 2020

[80] Prabu, H. J., Johnson, I. "Greener Cum Chemical Synthesis and Characterization of $\mathrm{Mg}$ Doped $\mathrm{ZnS}$ Nanoparticles and their Engineering Band Gap Performance", Journal of Engineering Research and Application, 5(8), pp. 99-105, 2015. [online] Available at: http://www.ijera.com/papers/Vol5_issue8/Part\%20 -\%204/M580499105.pdf [Accessed: 07 August 2018]

[81] Behnajady, M. A., Eskandarloo, H. "Characterization and Photocatalytic Activity of $\mathrm{Ag}-\mathrm{Cu} / \mathrm{TiO}_{2}$ Nanoparticles Prepared by Sol-gel Method", Journal of Nanoscience and Nanotechnology, 13(1), pp. 548-553, 2013.

https://doi.org/10.1166/jnn.2013.6859

[82] Shakir, M., Faraz, M., Sherwani, M. A., Al-Resayes, S. I. "Photocatalytic Degradation of the Paracetamol Drug Using Lanthanum Doped $\mathrm{ZnO}$ Nanoparticles and them in-Vitro Cytotoxicity Assay", Journal of Luminescence, 176, pp. 159-167, 2016.

https://doi.org/10.1016/j.jlumin.2016.03.027

[83] Tayade, R. J., Kulkarni, R. G., Jasra, R. V. "Transition Metal Ion Impregnated Mesoporous $\mathrm{TiO}_{2}$ for Photocatalytic Degradation of Organic Contaminants in Water", Industrial \& Engineering Chemistry Research, 45(15), pp. 5231-5238, 2006.

https://doi.org/10.1021/ie051362o 